\title{
Nanostructured $\mathrm{La}_{2} \mathrm{O}_{3}: \mathrm{Yb}^{3+} / \mathrm{Er}^{3+}$ : Temperature Sensing, Optical Heating and Bio-imaging Application
}

\author{
Zhen Sun ${ }^{\mathrm{a}}$, Guofeng Liu ${ }^{\mathrm{a}}$, Zuoling Fu ${ }^{\mathrm{a},{ }^{*}}$ Tianqi Sheng ${ }^{\mathrm{a}}$, Yanling Wei ${ }^{\mathrm{b}}$, Zhijian \\ $\mathbf{W u}^{\mathrm{c}}$ \\ ${ }^{a}$ Coherent Light and Atomic and Molecular Spectroscopy Laboratory, Key Laboratory of physics \\ and Technology for Advanced Batteries, College of Physics, Jilin University, Changchun 130012, \\ China, Fax: +86-431-85167966; Tel: +86-431-85167966; E-mail: zlfu@jlu.edu.cn(Z. L. Fu) \\ ${ }^{b}$ School of Media Matheatics \&Physics, Jilin Engineering Normal University, Changchun 130012, \\ China \\ ${ }^{c}$ State Key Laboratory of Rare Earth Resources Utilization, Changchun Institute of Applied \\ Chemistry, Chinese Academy of Sciences, Changchun 130022, China
}

\section{Abstract}

Nanostructured $\mathrm{Yb}^{3+} / \mathrm{Er}^{3+}$ co-doped $\mathrm{La}_{2} \mathrm{O}_{3}$ with intense green-light emission has been successfully synthesized by solvothermal method with further calcination. The prepared $\mathrm{La}_{2} \mathrm{O}_{3}: \mathrm{Yb}^{3+}, \mathrm{Er}^{3+}$ are composed of approximate spherical nanoparticles with the size of about $50 \mathrm{~nm}$. Optical temperature sensing performances depended on the thermally coupled levels of $\mathrm{Er}^{3+}$ are evaluated by analyzing temperature-dependent up-conversion luminescence (UCL) spectra, and the maximum sensitivity is 0.0040 $\mathrm{K}^{-1}$ at $315 \mathrm{~K}$ in the physiological working temperature range (295 K-315 K). Furthermore, the heating effect is also investigated, which causes the temperature of the samples to increase from 300 to $341 \mathrm{~K}$ with the variation of power density from 7.08 to $26.19 \mathrm{~W} / \mathrm{cm}^{2}$. In addition, cell toxicity experiment shows that the $\mathrm{La}_{2} \mathrm{O}_{3}$ has low cell cytotoxicity, and the confocal images of samples in HeLa cells are also obtained. All the results indicate that the nanostructured $\mathrm{La}_{2} \mathrm{O}_{3}: \mathrm{Yb}^{3+} / \mathrm{Er}^{3+}$ also may be used as fluorescent bio-imaging. 
Keywords: Solvothermal synthesis; Optical temperature sensing; Optical heater; Bio-imaging

\section{Introduction}

Temperature is a crucial parameter in the process of industrial production and scientific investigation. On the one hand, controlling temperature is beneficial to improve the efficiency of production and reduce energy consumption and environmental pollution for industrial manufacture. On the other hand, in biological research and biological engineer, temperature changes even in the tiny range may affect the lifetime of live cell. For example, so many biological experiments have testified that tumor cells can be killed when their ambient temperature is higher than $40{ }^{0} \mathrm{C}$ in the hyperthermia therapy [1-3]. With exactly monitoring temperature, health cells around the tumor can not be damaged. Real-time and hypersensitized the method of temperature measurement has become an urgent requirement for some treatment and diagnosis of the disease.

In the current, temperature measurement methods are mainly consist of two categories: contact methods (namely resistance temperature detector, thermocouples and thermistors) and noncontact methods including infrared thermography [4]. Among them, contact methods are not applied on complicated environment such as strong electromagnetic noise and corrosive chemical experiment. And noncontact methods can overcome such disadvantages by detecting infrared lighted that is emitted from the hot materials. However, infrared thermography has two characterized limitation: (i) the property of materials decides accuracy of temperature 
measurement. (ii) the infrared light is easily absorbed by water and glass in monitoring temperature, preventing their application in some research such as biomedicine [5,6]. Another fluorescence intensity ratio (FIR) technology as a kind of noncontact thermometry is gradually regarded as promising technology for optical temperature sensor. FIR technology monitoring temperature is based on the fluorescence intensity of the two thermally coupled of rare earth (RE) ions without the effect of spectrum losses and fluctuations, so it is free of low sensitivity and high environmental dependence [7-9]. Due to two thermally coupled levels ${ }^{2} \mathrm{H}_{11 / 2}$ and ${ }^{4} \mathrm{~S}_{3 / 2}$, doping $\mathrm{Er}^{3+}$ ions have become a good choice for temperature-depended sensor. For the enhancement of absorption cross-section of $980 \mathrm{~nm}$ laser, $\mathrm{Yb}^{3+}$ ions are usually called as sensitizer and doped into fluorescent materials [10, 11]. Nanoparticle which is much smaller than normal materials has advantage in decreasing light scattering and enhancing spatial resolution [12, 13]. And then upconversion nanoparticles (UCNPs) which can be excited by $980 \mathrm{~nm}$ laser and emit visible light include higher photochemical stability, deeper penetration and minimal autofluorescence [14]. To sum up, UCNPs will play more and more important role in the temperature sensor, scientific research and bio-imaging.

In some oxide hosts, $\mathrm{La}_{2} \mathrm{O}_{3}$ has many advantages which include plentiful mineral resources, low costs and low phonon energy $\left(\sim 400 \mathrm{~cm}^{-1}\right)$. So $\mathrm{Er}^{3+}-\mathrm{Yb}^{3+}$ doped $\mathrm{La}_{2} \mathrm{O}_{3}$ is a kind of valuable materials because of their high excitation efficiency, low toxicity, long luminescence lifetime and prominent stability [15]. Herein, the $\mathrm{Yb}^{3+}$ sensitized $\mathrm{Er}^{3+}$ doped $\mathrm{La}_{2} \mathrm{O}_{3}$ nanostructured materials are successfully synthesized by 
solvothermal methods with further calcination. The FE-SEM images exhibit that the average diameter of particles is about $50 \mathrm{~nm}$. The UCL excited by $980 \mathrm{~nm}$ diode laser have been investigated in $\mathrm{Er}^{3+} / \mathrm{Yb}^{3+}$ co-doped $\mathrm{La}_{2} \mathrm{O}_{3}$ nanostructured materials. The fluorescence intensity ratio (FIR) from ${ }^{2} \mathrm{H}_{11 / 2}$ and ${ }^{4} \mathrm{~S}_{3 / 2}$ levels to ${ }^{4} \mathrm{I}_{15 / 2}$ of $\mathrm{Er}^{3+}$ are used to investigate the optical temperature sensing properties especially in the physiological working temperature range (295 K-315 K). Moreover, the heating effect by $980 \mathrm{~nm}$ laser which introduced the temperature of $\mathrm{La}_{2} \mathrm{O}_{3}$ to change from $300 \mathrm{~K}$ to $341 \mathrm{~K}$ with the power density in the range of $7.08-26.19 \mathrm{~W} / \mathrm{cm}^{2}$ could be used in biothermal treatment. Its cell cytotoxicity and cell imaging are also explored. All the experimental results indicate that the $\mathrm{La}_{2} \mathrm{O}_{3}: \mathrm{Yb}^{3+} / \mathrm{Er}^{3+}$ nanoparticle may be promising materials in the field of fluorescent bio-imaging, nanothermometry and photothermal therapy.

\section{Experimental Procedure}

\subsection{Sample preparation}

Materials. The $\mathrm{Er}^{3+}-\mathrm{Yb}^{3+}$ codoped $\mathrm{La}_{2} \mathrm{O}_{3}$ nanocrystalline phosphors were successfully synthesized by solvothermal method. All the chemicals were used without further purification and commercially available.

Synthesis of $\mathbf{E r}^{3+}-\mathbf{Y b}^{3+}$ codoped $\mathrm{La}_{2} \mathbf{O}_{3}$. Rare earth nitrate $\left(0.01 \mathrm{M} \mathrm{Er}\left(\mathrm{NO}_{3}\right)_{3}\right.$ and $\left.0.02 \mathrm{M} \mathrm{Yb}\left(\mathrm{NO}_{3}\right)_{3}\right)$ stock solutions and $\mathrm{La}\left(\mathrm{NO}_{3}\right)_{3} \cdot 6 \mathrm{H}_{2} \mathrm{O}(99.9 \%)$ were used as the starting materials. In a typical procedure, $0.01 \mathrm{M} \mathrm{Er}\left(\mathrm{NO}_{3}\right)_{3}, 0.02 \mathrm{M} \mathrm{Yb}\left(\mathrm{NO}_{3}\right)_{3}$, 2.1651g $\mathrm{La}\left(\mathrm{NO}_{3}\right)_{3} \cdot 6 \mathrm{H}_{2} \mathrm{O}$ and $40 \mathrm{~mL}$ aqueous ammonia were added in Ethylene glycol solution to form a mixing solution. Then agitation for $2 \mathrm{~h}$ again, the 
as-obtained mixing solution was poured into a Teflon bottle held in a stainless steel autoclave, sealed and kept at $200^{\circ} \mathrm{C}$ for $10 \mathrm{~h}$. Then, the obtained precipitates were washed many times with ethanol. Subsequently, the precipitates were dried at $90^{\circ} \mathrm{C}$ for $12 \mathrm{~h}$. Finally, the precursor was dried and calcined at $800^{\circ} \mathrm{C}$ for $2 \mathrm{~h}$. In this way, the $\mathrm{La}_{2} \mathrm{O}_{3}$ nanoparticles were obtained.

\subsection{Cell cytotoxicity assay}

3-(4,5-dimethylthiazol-2-yl)-2,5,-diphenyltetrazolium bromide (MTT) proliferation assay was applied to measure cell viability. At first, the HeLa cells were seeded in 96-well microplate, and $\mathrm{HeLa}$ cells and $\mathrm{La}_{2} \mathrm{O}_{3}: \mathrm{Er}^{3+}, \mathrm{Yb}^{3+}$ with concentrations from 3.125 to $100 \mu \mathrm{g} / \mathrm{mL}$ in growth medium incubated for 24 hours at $37{ }^{0} \mathrm{C}$ and $5 \% \mathrm{CO}_{2}$. Then, $100 \mu \mathrm{L}$ MTT $(0.5 \mathrm{mg} / \mathrm{mL}$ in PBS solution) were added in each well to incubate again for 4 hours at $37^{\circ} \mathrm{C}$. At last, removing growth medium and adding DMSO to each well, the microplate was placed at room for $2 \mathrm{~h}$.

\subsection{Cell imaging}

Firstly, the HeLa cells were cultured in Dulbecco minimum essential media (MEM- $\alpha$ ) including $10 \%$ fetal bovine serum (FBS), $1 \%$ penicillin, and $1 \%$ amphotericin B. And then, HeLa cells were seeded in $35 \mathrm{~mm}$ culture dishes the day before experiment. In the process of experiment, the $\mathrm{La}_{2} \mathrm{O}_{3}$ nanocrystalline that was dispersed into aqueous solution were add to HeLa cells with incubating 24 hours at $37^{\circ} \mathrm{C}$ and $5 \% \mathrm{CO}_{2}$. Cellular imaging was got by confocal laser scanning microscope (Olympus, FV 1000) equipped with the Nuance GNIR CCD camera, $980 \mathrm{~nm}$ laser as pump source focused on the wells. 


\subsection{Characterization}

The characterization of the structure and crystalline phase was recorded on a Rigaku-Dmax 2500 diffractometer at a scanning rate of $15 \%$ min in the $2 \theta$ range from $10^{\circ}$ to 80 using $\mathrm{Cu} \mathrm{K \alpha}$ radiation $(\lambda=0.15405 \mathrm{~nm})$. The field emission-scanning electron microscope (FE-SEM, XL30, Philips) examined morphology and size of the obtained samples. The Andor Shamrock SR-750 fluorescence spectrometer measured the UCL spectra. The signal of the samples were collected from 450 to $700 \mathrm{~nm}$ by A CCD detector combined with a monochromator. A $980 \mathrm{~nm}$ diode which was coupled to a fiber (the core diameter $200 \mathrm{~mm}$, numerical aperture 0.22) laser was used as the pump source. Andor SR-500i spectrometer (Andor Technology Co, Belfast, UK) was used to record the luminescence spectra by exciting the samples with $980 \mathrm{~nm}$. The $\mathrm{Yb}^{3+} / \mathrm{Er}^{3+}$ co-doped $\mathrm{La}_{2} \mathrm{O}_{3}$ samples were loaded in an iron sample cell and the temperature of the sample increased from 313 to $573 \mathrm{~K}$ heated by resistive wire elements.

\section{Results and Discussion}

\subsection{X-ray Diffraction Analysis and Morphology}

XRD and FE-SEM. To explore the phase purity and crystal structure, the $\mathrm{La}_{2} \mathrm{O}_{3}$ : $\mathrm{xEr}^{3+}, \mathrm{yYb}^{3+}$ have been measured by XRD. The diffraction peaks of all samples prepared in our experiments show similar results, the XRD patterns of $\mathrm{La}_{2} \mathrm{O}_{3}: \mathrm{xEr}^{3+}$, $\mathrm{yYb}^{3+}((\mathrm{a}) \mathrm{x}=1 \mathrm{~mol} \% ; \mathrm{y}=1 \%, 3 \%, 4$ mol\%; (b) $\mathrm{y}=2$ mol\%; $\mathrm{x}=1 \%, 5$ mol\%) are presented in Figure 1 as representative examples. The XRD patterns of the obtained samples are exactly in agreement with the standard characteristic peaks of $\mathrm{La}_{2} \mathrm{O}_{3}$ 
structure (JCPDS no. 05-0602). Among these diffraction peaks, the strongest peak can be observed to be placed near $2 \theta=30.15^{\circ}$. This diffraction peak corresponds to (101) plane. Other diffraction peaks are detected at $2 \theta=26.28^{\circ}, 29.29^{\circ}, 39.69^{\circ}, 46.25^{\circ}$, $52.32^{\circ}, 55.70^{\circ}, 56.22^{\circ}$. The crystallite size of the sample has been calculated by Scherrer equation as follows [16]

$D=\frac{0.9 \lambda}{\beta \cos \theta}$

where $\lambda$ is the wavelength of the X-ray (1.5405 $\AA), \beta$ is the half-width after subtracting the instrumental broadening, $\theta$ is diffraction angle for the given peak, $\mathrm{D}$ is the crystallite size. The average crystallite size of $\mathrm{La}_{2} \mathrm{O}_{3}: \mathrm{Er}^{3+}, \mathrm{Yb}^{3+}$ nanocrystallines has been calculated and found to be $44 \mathrm{~nm}$.

At the same time, the typical FE-SEM images of the $\mathrm{La}_{2} \mathrm{O}_{3}$ sample prepared by solvothermal synthesis are revealed in Figure 2. From Figure 2(a) and (b) in the scale of 500, $300 \mathrm{~nm}$, it can be observed that the nanostructured $\mathrm{La}_{2} \mathrm{O}_{3}$ particle mostly crystallized in spherical form with the mean particles size of about $50 \mathrm{~nm}$. On the whole, the crystallite size of $\mathrm{La}_{2} \mathrm{O}_{3}$ in the FE-SEM pictures accords with the results that are calculated by Scherrer equation.

\subsection{UCL of $\mathrm{La}_{2} \mathrm{O}_{3}: \mathrm{Er}^{3+}, \mathrm{Yb}^{3+}$ nanocrystallines}

Concentration dependence of UC spectrum. Under $980 \mathrm{~nm}$ excitation, Figure 3 illustrates the UC emission spectra of the $\mathrm{Er}^{3+} / \mathrm{Yb}^{3+}$ co-doped $\mathrm{La}_{2} \mathrm{O}_{3}$ nanocrystallines with further calcination at $800^{\circ} \mathrm{C}$. The UC emission bands are observed around 530 $\mathrm{nm}\left({ }^{2} \mathrm{H}_{11 / 2} \rightarrow{ }^{4} \mathrm{I}_{15 / 2}\right), 549 \mathrm{~nm}\left({ }^{4} \mathrm{~S}_{3 / 2} \rightarrow{ }^{4} \mathrm{I}_{15 / 2}\right)$ and $671 \mathrm{~nm}\left({ }^{4} \mathrm{~F}_{9 / 2} \rightarrow{ }^{4} \mathrm{I}_{15 / 2}\right)$. In Figure 3(a), the room-temperature UC emission intensities keep $\mathrm{Yb}^{3+}$ ions concentration at fixed 
$0.02 \mathrm{~mol}, \mathrm{Er}^{3+}$ concentrations vary from 0.005 to $0.05 \mathrm{~mol}$. At the same time, Figure 3(b) shows the concentrations of $\mathrm{Yb}^{3+}$ ions in the co-doped $\mathrm{La}_{2} \mathrm{O}_{3}$ nanocrystallines vary from 0.01 to $0.05 \mathrm{~mol}$, the $\mathrm{Er}^{3+}$ ions concentration is fixed at $0.01 \mathrm{~mol}$. As shown in Figure 3(a) and (b), it is observed that the spectral properties and UCL intensities rely on doping concentrations. As shown in Figure 3(a), it can be observed that

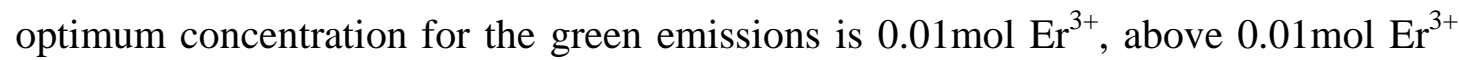
concentration, gradual quenching of emission occurred as a result of concentration quenching. Furthermore, the occurrence of concentration quenching may result from energy transfer between the nearest $\mathrm{Er}^{3+}$ and $\mathrm{Yb}^{3+} / \mathrm{Er}^{3+}$ ions. When the concentration of $\mathrm{Er}^{3+}$ is above $0.01 \mathrm{~mol}$, the distance between $\mathrm{Er}^{3+}$ and $\mathrm{Yb}^{3+} / \mathrm{Er}^{3+}$ ions will be reduced, which strengthens nonradiative relaxation and causes the decrease in UCL intensity [17]. The Figure 3(b) indicates the UCL intensities decrease extraordinarily with the increasing $\mathrm{Yb}^{3+}$ above $0.02 \mathrm{~mol}$. Therefore, the better luminous one of these $\mathrm{La}_{2} \mathrm{O}_{3}$

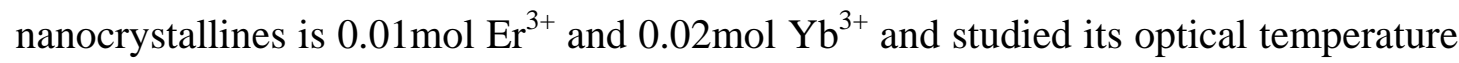
sensing and optical heated properties, which will be discussed in the next part.

\subsection{Energy Diagram and Pump Power Study}

Mechanism of UC emission. In order to understand UC processes and UC mechanism, Figure 4 and 5 respectively display possible double logarithmic plots of the two green emission intensities for with different pump power $\mathrm{P}_{980}$ and possible UC process. In Figure 4, the relationship of the UCL intensity $\left(I_{U C}\right)$ and the pump power ( $\left.P_{\text {pump }}\right)$ can be expressed as

$$
I_{U C} \propto\left(P_{\text {pump }}\right)^{n},
$$


where $\mathrm{n}$ is the number of laser photons used to occupied the upper emission state, $I_{U C}$ and $P_{\text {pump }}$ represent respectively the UCL intensity and power [18-20]. It can be found that the slopes of the three fitted lines corresponding to 530, 549 and 672nm emission are 2.3, 1.9 and 1.8, respectively. Therefore, the $\mathrm{n}$ values reveal that green and red UC emission are two-photon process and two NIR excitation photons are absorbed to emit one green or red UC photon in the $\mathrm{La}_{2} \mathrm{O}_{3}$ : $\mathrm{Er}^{3+} / \mathrm{Yb}^{3+}$ samples [21].

As shown in Figure 5, we can further understand UC luminance process. The $\mathrm{Yb}^{3+}$ ions at ${ }^{2} \mathrm{~F}_{7 / 2}$ can be excited to ${ }^{2} \mathrm{~F}_{5 / 2}$ under $980 \mathrm{~nm}$ lasers pumping. Then ET step occurs between $\mathrm{Yb}^{3+}$ and $\mathrm{Er}^{3+}$ ions, the ${ }^{4} \mathrm{I}_{11 / 2}$ level of $\mathrm{Er}^{3+}$ ions is populated. The ${ }^{4} \mathrm{I}_{11 / 2}$ level of $\mathrm{Er}^{3+}$ is excited to ${ }^{4} \mathrm{~F}_{7 / 2}$ state by the ESA or ET. And multiphonon relaxation (MPR) occurs and jumps to the lower levels ${ }^{2} \mathrm{H}_{11 / 2}\left({ }^{4} \mathrm{~S}_{3 / 2}\right)$. The green emissions and red emissions are observed due to the radiative relaxation from the ${ }^{2} \mathrm{H}_{11 / 2}\left({ }^{4} \mathrm{~S}_{3 / 2}\right)$ and ${ }^{4} \mathrm{~F}_{9 / 2}$ level to ${ }^{4} \mathrm{I}_{15 / 2}$ level of $\mathrm{Er}^{3+}[22,23]$.Among these bands, the intensities of red bands are more obvious than green emitting due to cross-relaxation (CR) and energy back transfer (EBT) which are also explained from Figure 5 between $\mathrm{Er}^{3+}$ and $\mathrm{Yb}^{3+}$ ions. The CR process from the excited state ${ }^{4} \mathrm{~S}_{3 / 2}$ of $\mathrm{Er}^{3+}\left({ }^{4} \mathrm{~S}_{3 / 2} \rightarrow{ }^{4} \mathrm{I}_{13 / 2}\right)$ to the ground state of $\mathrm{Yb}^{3+}\left({ }^{2} \mathrm{~F}_{7 / 2} \rightarrow{ }^{2} \mathrm{~F}_{5 / 2}\right)$ and sequential step is the EBT which is from the $\mathrm{Yb}^{3+}\left({ }^{2} \mathrm{~F}_{5 / 2} \rightarrow{ }^{2} \mathrm{~F}_{7 / 2}\right)$ to the $\mathrm{Er}^{3+}\left({ }^{4} \mathrm{I}_{13 / 2} \rightarrow{ }^{4} \mathrm{~F}_{9 / 2}\right)$ with the increase of $\mathrm{Yb}^{3+}$ and $\mathrm{Er}^{3+}$ concentration, so the two processes are helpful to enhanced the population of ${ }^{4} \mathrm{~F}_{9 / 2}$. In conclusion, The CR and EBT processes induced green emission weaker than red emission [24].

\subsection{Temperature Sensing Behavior}

The UCL properties which are related with temperature of $\mathrm{La}_{2} \mathrm{O}_{3}: \mathrm{Er}^{3+}, \mathrm{Yb}^{3+}$ 
nanocrystalline has been studied according to the different intensities ratio from two closely thermally coupled levels to regard potentials as optical temperature sensing. It can also been seen that the population obeyed Boltzmann distribution in the thermally coupled levels [23, 25]. Figure 6 exhibits the UC emission spectra of $0.01 \mathrm{~mol} \mathrm{Er}^{3+}$, $0.02 \mathrm{~mol} \mathrm{Yb}^{3+}$ codoped $\mathrm{La}_{2} \mathrm{O}_{3}$ nanocrystalline annealed at $800^{\circ} \mathrm{C}$ from $313 \mathrm{~K}$ to $573 \mathrm{~K}$ and the pump power is set up at $0.6 \mathrm{~W}$. It can be found interestingly that the $\mathrm{R}$ increases clearly with the increase of temperature. In the thermalization process the ${ }^{2} \mathrm{H}_{11 / 2}$ level can be populated effectively from ${ }^{4} \mathrm{~S}_{3 / 2}$, therefore relative intensities between the two thermally coupled levels have changed. Subsequently, it is also observed that the $\mathrm{R}$ increase with increasing temperature. It is well known that the population of each energy level related with the emission intensities, so the $\mathrm{R}$ from two green emissions can be defined in this way [26-28].

$$
\mathrm{R}=\frac{\mathrm{N}_{2}}{\mathrm{~N}_{1}}=\frac{I_{2 \mathrm{j}}}{I_{1 j}}=\frac{g_{2} \sigma_{2 j} \omega_{2 j}}{g_{1} \sigma_{1 j} \omega_{1 j}} \exp \left[\frac{-\Delta E}{K_{B} T}\right]=B \exp \left[\frac{-\Delta E}{K_{B} T}\right]
$$

Where

$$
B=\frac{g_{2} \sigma_{2 j} \omega_{2 j}}{g_{1} \sigma_{1 j} \omega_{1 j}}
$$

$\mathrm{N}, \mathrm{g}, \sigma, \omega$ represent ions, the degeneracy, the emission cross-section, the angular frequency of fluorescence two transitions. $I_{2 j}$ and $I_{1 j}$ are the intensities of the ${ }^{2} \mathrm{H}_{11 / 2} \rightarrow$ ${ }^{4} \mathrm{I}_{15 / 2}(513 \mathrm{~nm}-539 \mathrm{~nm})$ and ${ }^{4} \mathrm{~S}_{3 / 2} \rightarrow{ }^{4} \mathrm{I}_{15 / 2}$ (539nm-574nm), respectively. $\Delta E$ is the energy difference between the ${ }^{2} \mathrm{H}_{11 / 2}$ and ${ }^{4} \mathrm{~S}_{3 / 2}$ levels, $\mathrm{k}_{\mathrm{B}}$ represents the Boltzmann constant and $\mathrm{T}$ shows the absolute temperature [27].

Figure 7(a) illustrates R ( $\left.\mathrm{I}_{530} / \mathrm{I}_{549}\right)$ of green emission bands at $530 \mathrm{~nm}$ and $549 \mathrm{~nm}$ 
and 1/T obey function relation ranging from 313 to $573 \mathrm{~K}$. By linear fitting, the slope of the line is about 1183 , which really gives the $\frac{-\Delta E}{k_{B}}$ value. According to the fitting parameter the calculated value of $\Delta E$ is $822.4 \mathrm{~cm}^{-1}$. The Figure $7(\mathrm{~b})$ exhibits the variation of $\mathrm{R}$ with different temperature, in which the $\mathrm{R}$ values increased from 0.34 to 1.84 from $313 \mathrm{~K}$ to $573 \mathrm{~K}$. The calculated value of B was 14.44. Meanwhile, the accuracy of measured temperature which is an important value for temperature sensor can be estimated by the followed formula:

$$
\Delta \mathrm{T}=\Delta \mathrm{R} \times \frac{\mathrm{K}_{\mathrm{B}} \mathrm{T}^{2}}{\mathrm{R} \Delta \mathrm{E}}
$$

Where the $\Delta T$ is the error in the measured temperature and the $\Delta R$ is varied with FIR. The error in measured temperature is obtained to be $\pm 0.23 \mathrm{~K}$ that indicates the high accuracy of prepared samples for optical temperature sensing purposes [29].

The sensitivity is an important parameter in quantitatively ensuring an optical sensor and is defined as the rate of $\mathrm{R}$ varying with absolute temperature and can be expressed as [30]:

$$
S=\frac{d R}{d T}=R\left[\frac{\Delta E}{K_{B} T^{2}}\right]=B \frac{\Delta E}{k_{B} T^{2}} \exp \left[\frac{-\Delta E}{K_{B} T}\right]
$$

The sample of $\mathrm{La}_{2} \mathrm{O}_{3}: 0.01 \mathrm{~mol} \mathrm{Er}{ }^{3+}, 0.02 \mathrm{~mol} \mathrm{Yb}^{3+}$ nanocrystalline according to curve exhibiting the variation of sensitivity with temperature from 313 to $573 \mathrm{~K}$ is showed in Figure 8. It can be obviously found that the maximum sensitivity is about $0.0066 \mathrm{~K}^{-1}$ at $573 \mathrm{~K}$ and keeps increasing with temperature in our experimental range, and the maximum sensitivity is $0.0040 \mathrm{~K}^{-1}$ at $315 \mathrm{~K}$ in the physiological working temperature range (295 $\mathrm{K}-315 \mathrm{~K})$. The result shows that the $\mathrm{La}_{2} \mathrm{O}_{3}: 0.01 \mathrm{~mol} \mathrm{Er}^{3+}$, 
$0.02 \mathrm{~mol} \mathrm{Yb}^{3+}$ nanocrystalline can be regarded as potential temperature sensing materials.

\subsection{Analysis of Optical Heater}

In order to study the influence of the laser induced thermal effect, under different power excitation, the green emission spectra of samples and plot of the calculated $\mathrm{R}$ ( $\mathrm{I}_{530} / \mathrm{I}_{549}$ ) were shown in Figure 9 and the calculated values were exhibited in Table 1. It can be seen that the value of $\mathrm{R}$ rises from 0.28 to 0.40 when the power density increases from 7.08 to $20.52 \mathrm{~W} / \mathrm{cm}^{2}$. In terms of the optical temperature sensing properties, $\mathrm{R}$ value can represent a particular temperature, so under different pump powers, the substrate temperature heated under the excitation of $980 \mathrm{~nm}$ laser can be written by following Eq. (4) which is rearranged from Eq. (1) [31]:

$T=\left[\frac{1}{\ln B-\ln R}\right]\left[\frac{\Delta E}{K_{B}}\right]$

Where all the terms have their usual implications as mentioned Eq. (1). The lattice temperature varies from 300 to $341 \mathrm{~K}$ with increasing of power density from 7.08 to $26.19 \mathrm{~W} / \mathrm{cm}^{2}$. According to above results, the generation of heat becomes prominent by non-radiative relaxation at pump power. In general, the charged mobile is induced by the laser electric field strongly inside the crystalline, and the obtained energy transfer to heat by electron-phonon coupling. Heat produced spreads away from the crystalline and causes an increase in temperature of the nearby volume. At the same time, the enhanced electron-phonon interaction also occurred and led to extra heating of crystalline in crystalline. With temperature enhance, the electron-phonon interaction increases [32, 33]. In summary, $\mathrm{Yb}^{3+} / \mathrm{Er}^{3+}$ co-doped $\mathrm{La}_{2} \mathrm{O}_{3}$ phosphors have 
also great potential materials as an optical heater.

\subsection{Cell cytotoxicity test and the UCL imaging of living cells in vitro}

As we all know, cell toxicity determined whether the samples were suit for bio-imaging. The viability of $\mathrm{HeLa}$ cells with different concentration of $\mathrm{La}_{2} \mathrm{O}_{3}$ : 0.01mol Er ${ }^{3+}, 0.02 \mathrm{~mol} \mathrm{Yb}^{3+}$ was measured by MTT methods. The Figure 10 displays that the samples have a low cell toxicity to HeLa cells. Even at the most high dosage of $100 \mu \mathrm{g} / \mathrm{mL}$, cell viability is more than $80 \%$. Under $980 \mathrm{~nm}$ excitation, Figure 11 shows confocal microscopy images of HeLa cells, green light emission is displayed in Figure 11(b). It can be observed from the overlay (Figure 11 (c)) of bright-field images (Figure 11 (a)) and confocal image that brightly luminescent are visible in the cells, which indicates that the luminescence comes from the HeLa cells and the $\mathrm{La}_{2} \mathrm{O}_{3}$ : $\mathrm{Er}^{3+} / \mathrm{Yb}^{3+}$ has been internalized into the cells [34]. On the whole, $\mathrm{La}_{2} \mathrm{O}_{3}: \mathrm{Er}^{3+} / \mathrm{Yb}^{3+}$ has a low cell toxicity and may be regarded as bio-imaging materials.

\section{Conclusion}

The $\mathrm{Yb}^{3+}$ and $\mathrm{Er}^{3+}$ co-doped $\mathrm{La}_{2} \mathrm{O}_{3}$ nanocrystallines with different dopant concentrations are successfully prepared by solvothermal synthesis with further calcination. The XRD and FE-SEM indicate that the $\mathrm{La}_{2} \mathrm{O}_{3}: 0.01 \mathrm{~mol} \mathrm{Er}^{3+}, 0.02 \mathrm{~mol}$ $\mathrm{Yb}^{3+}$ prepared by solvothermal synthesis methods is pure phase, and the average diameter of nanocrystallines is about $50 \mathrm{~nm}$. Furthermore, the optimal green emission can be observed in $\mathrm{La}_{2} \mathrm{O}_{3}: 0.01 \mathrm{~mol} \mathrm{Er} r^{3+}, 0.02 \mathrm{~mol} \mathrm{Yb}^{3+}$ under the $980 \mathrm{~nm}$ excitation. The $\mathrm{R}$ of the green bands is related with temperature to examine its temperature sensing behavior. The maximum sensitivity of the nanocrystalline with optimal 
dopant concentration is $0.0066 \mathrm{~K}^{-1}$ at $573 \mathrm{~K}$. Moreover, the heating effect is also investigated, and the temperature of sample increase from 300 to $341 \mathrm{~K}$ with an increase of power density from 7.08 to $26.19 \mathrm{~W} / \mathrm{cm}^{2}$. The $\mathrm{Er}^{3+}$ and $\mathrm{Yb}^{3+}$ codoped $\mathrm{La}_{2} \mathrm{O}_{3}$ nanocrystallines has a low cell toxicity, and the confocal images of samples in HeLa cells are also obtained. The experimental results can help us to increase our understanding of the multifunctional $\mathrm{La}_{2} \mathrm{O}_{3}$ nanostructured materials and develop their future applications.

\section{Acknowledgments}

This work was supported by the Science and Technology Development Planning Project of Jilin Province (20160101294JC), partially sponsored by China Postdoctoral Science Foundation and by the National Science Foundation of China (no. 21521092), supported by the National Found for Fostering Talents of Basic Science (no. J1103202) and by the Outstanding Young Teacher Cultivation Plan in Jilin University. 


\section{References}

[1] P. Wust, B. Hildebrandt, G. Sreenivasa, B. Rau, J. Gellermann, H. Riess, R. Felix, P. M. Schlag, Hyperthermia in combined treatment of cancer, Lancet Onco. 3 (2002) 487-497.

[2] B. Hildebrandt, P. Wust, O. Ahlers, A. Dieing, G. Sreenivasa, T. Kerner, R. Felix, H. Riess, The cellular and molecular basis of hyperthermia, Crit. Rev. Oncol. Hematol. $43(2002) 33-56$.

[3] J. H. Son, B. Cho, S. G. Hong, S. H. Lee, O. Hoxha, A.J. Haack and L. P. Lee, Ultrafast photonic PCR, Light: Science \& Applications. 4 (2015) e280-e287 .

[4] S. P. Wang, S.Westcott, W. Chen, Nanoparticle Luminescence Thermometry, J. Phys. Chem. B. 106 (2002) 11203-11209.

[5] B. B. Lowell, B. M. Spiegelman, Towards a molecular understanding of adaptive thermogenesis, Nature. 404 (2000) 652-660.

[6] E. Tanaka, M. Yamamura, A. Yamakawa, T. Fujise, S. Nakano, Microcalorimetric measurements of heat production in isolated rat brown adipocytes, Biochem. Int. 26 (1992) 873-877.

[7] K. C. Liu, Z. Y. Zhang, C. X. Shan, Z. Q. Feng, J. S. Li, C. L. Song, Y. N. Bao, X. H. Qi and B. Dong, A flexible and superhydrophobic upconversion-luminescence membrane as an ultrasensitive fluorescence sensor for single droplet detection, Light: Science \&Applications. 5 (2016) e16136-e16143.

[8] V. K. Rai, A. Pandey, R. Dey, $\mathrm{Er}^{3+}-\mathrm{Yb}^{3+}$ and $\mathrm{Eu}^{3+}-\mathrm{Er}^{3+}-\mathrm{Yb}^{3+}$ codoped $\mathrm{Y}_{2} \mathrm{O}_{3}$ phosphors as optical heater, J. Appl. Phys. 113 (2013) 83104-83110.

[9] B. P. Singh, A. K. Parchur, R. S. Ningthoujam, P. V. Ramakrishna, S. Singh, P. Singh, S. B. Raib, R. Maalej, Enhanced up-conversion and temperature-sensing behaviour of $\mathrm{Er}^{3+}$ and $\mathrm{Yb}^{3+}$ co-doped $\mathrm{Y}_{2} \mathrm{Ti}_{2} \mathrm{O}_{7}$ by incorporation of $\mathrm{Li}^{+}$ions, Phys. 
Chem. Chem. Phys. 16 (2014) 22665-22676.

[10] A.k. Soni, V.K. Rai, M.K. Mahata, $\mathrm{Yb}^{3+}$ sensitized $\mathrm{Na}_{2} \mathrm{Y}_{2} \mathrm{~B}_{2} \mathrm{O}_{7}: \mathrm{Er}^{3+}$ phosphors in enhanced frequency upconversion, temperature sensing and field emission display, Mater. Res. Bull. 89 (2017) 116-124.

[11] T. Wei, Y. Shi, Y.F. Xie, Z. Dong, C.Z. Zhao, Q.J. Zhou, C.C. Ding, S. Yuan, F.Y. Xiang, X. Guo, B.Y. Du, High temperature-sensing performance of Er- and Yb-codoped tungsten bronze oxides based on frequency up-conversion luminescence, Mater. Res. Bull. 88 (2017) 206-213.

[12] Alivisatos, Semiconductor clusters, nanocrystals, and quantum dots, A. P. Science, 271 (1996) 933-937.

[13] K. Kůsová, I. Pelant and J. Valenta, Bright trions in direct-band gap silicon nanocrystals revealed by low-temperature single-nanocrystal spectroscopy, Light: Science \&Applications, 4 (2015) e336-e344.

[14] F. Zhang, G. B. Braun, Y. F. Shi, Y. C. Zhang, X. H. Sun, N. O. Reich, D. Y. Zhao, G. Stucky, Fabrication of Ag@SiO $@_{2} @ \mathrm{Y}_{2} \mathrm{O}_{3}$ :Er Nanostructures for Bioimaging: Tuning of the Upconversion Fluorescence with Silver Nanoparticles, J. Am. Chem. Soc. 132 (2010) 2850-2851.

[15] G. G. Li, C. X. Li, Z. H. Xu, Z. Y. Cheng and J. Lin, Facile synthesis, growth mechanism and luminescence properties of uniform $\mathrm{La}(\mathrm{OH})_{3}: \mathrm{Ho}^{3+} / \mathrm{Yb}^{3+}$ and $\mathrm{La}_{2} \mathrm{O}_{3}: \mathrm{Ho}^{3+} / \mathrm{Yb}^{3+}$ nanorods, CrystEngComm. 12 (2010) 4208-4216.

[16] R. Dey, V.K. Rai, $\mathrm{Yb}^{3+}$ sensitized $\mathrm{Er}^{3+}$ doped $\mathrm{La}_{2} \mathrm{O}_{3}$ phosphor in temperature sensors and display devices, Dalton Trans., 43 (2014) 111-118.

[17] J. H. Chung, et al., Green Upconversion Luminescence from Poly-Crystalline 
$\mathrm{Yb}^{3+}, \mathrm{Er}^{3+}$ Co-Doped $\mathrm{CaMoO}_{4}$, J. Alloys. Compd. 522 (2012) 30-34.

[18] M. Pollnau, D. R. Gamelin, S. R. Luthi, H. U. Gudel and M. P. Hehlen, Power dependence of upconversion luminescence in lanthanide and transition-metal-ion systems, Phys. Rev. B. 61 (2001) 3337-3346.

[19] X. Wu, J. P. Denis, Q. Ph and F. Pellé, The UV, blue and green up-conversion luminescence of $\mathrm{PbF}_{2}+\mathrm{GeO}_{2}$ : $\mathrm{Er}_{2} \mathrm{O}_{3}$ pumped with $650 \mathrm{~nm}$, Appl. Phys. B: Laser Opt. 56 (1993) 269-273.

[20] M. A. Chamarro and R. Cases, Infrared to visible upconversion of $\mathrm{Er}^{3+}$ ions in $\mathrm{Yb}^{3+}$ doped fluorohafnate glasses, J. Lumin. 46 (1990) 59-65.

[21] R. Dey, A. Pandey, V.K. Rai, The $\mathrm{Er}^{3+}-\mathrm{Yb}^{3+}$ codoped $\mathrm{La}_{2} \mathrm{O}_{3}$ phosphor in finger print detection and optical heating, Spectrochim. Acta. A. 128 (2014) 508-513.

[22] J. Zhang, S. W. Wang, T. J. Rong and L. D. Chen, Upconversion Luminescence in $\mathrm{Er}^{3+}$ Doped and $\mathrm{Yb}^{3+} / \mathrm{Er}^{3+}$ Codoped Yttria Nanocrystalline Powders, J. Am. Ceram. Soc, 87 (2004) 1072-1075.

[23] O. Svelto, Principles of Lasers, 3rd ed. Plenum, New York, 1989.

[24] J. H. Zhang, Z. D. Hao, J. Li, X. Zhang, Y.S. Luo, G. H. Pan, Observation of efficient population of the red-emitting state from the green state by non-multiphonon relaxation in the $\mathrm{Er}^{3+}-\mathrm{Yb}^{3+}$ system, Light: Science \& Applications. 4 (2015) e239-e245.

[25] S. A. Wade, S.F. Collins, and G.W. Baxter, Fluorescence intensity ratio technique for optical fiber point temperature sensing, J. Appl. Phys. 94 (2003) 4743-4754.

[26] D.Q. Chen, W. Xu, Y. Zhou, Y. Chen, Lanthanide doped $\mathrm{BaTiO}_{3}-\mathrm{SrTiO}_{3}$ solid-solution phosphors: Structure, optical spectroscopy and upconverted temperature sensing behavior, J. Alloy. Compd. 676 (2016) 215-223 
[27] S. F. Collins, G. W. Baxter, S. A. Wade, T. Sun, K. T. V. Grattan, Z. Y. Zhang and A. W. Palmer, Comparison of fluorescence-based temperature sensor schemes: Theoretical analysis and experimental validation, J. Appl. Phys. 84 (1998) 4649-4654. [28] M. D. Shinn, W. A. Sibley, M. G. Drexhage and R. N. Brown, Optical transitions of $\mathrm{Er}^{3+}$ ions in fluorozirconate glass, Phys. Rev. B. 27 (1983) 6635-6648.

[29] E. Maurice, G. Monnom, B. Dussardier, A. Saïssy, D.B. Ostrowsky, G.W. Baxter, Erbium-doped silica fibers for intrinsic fiber-optic temperature sensors, Appl. Opt. 34 (1995) 8019-8025.

[30] K. Z. Zheng, Z. Y. Liu, C. J. Lv and W. P. Qin, Temperature sensor based on the $\mathrm{UV}$ upconversion luminescence of $\mathrm{Gd}^{3+}$ in $\mathrm{Yb}^{3+}-\mathrm{Tm}^{3+}-\mathrm{Gd}^{3+}$ codoped $\mathrm{NaLuF}_{4}$ microcrystals, J. Mater. Chem. C. 1 (2013) 5502-5507.

[31] M. Challenor, P. J. Gong, D. Lorenser, M. Fitzgerald, S. Dunlop, D. D. Sampson and K. S. Iyer, Iron Oxide-Induced Thermal Effects on Solid-State Upconversion Emissions in $\mathrm{NaYF}_{4}$ : Yb,Er Nanocrystals, ACS Appl. Mater. Interfaces. 5 (2013) 7875-7880.

[32] Kikhomirov VK, Driesen K, Rodriguez VD, Gredin P, Mortier M, Moshchalkov VV, Optical nanoheater based on the $\mathrm{Yb}^{3+}-\mathrm{Er}^{3+}$ co-doped nanoparticles, Opt Express. 17 (2009) 11794-11798.

[33] R. K. Verma, S. B. Rai, Laser induced optical heating from $\mathrm{Yb}^{3+} / \mathrm{Ho}^{3+}: \mathrm{Ca}_{12} \mathrm{Al}_{14} \mathrm{O}_{33}$ and its applicability as a thermal probe, J. Quant. Spectrosc. Radiat. Transfer. 13 (2012) 1594-1600.

[34] D. Yin, C.C. Wang, J. Ouyang, K. Song, B. Liu , X.Z. Cao, L. Zhang, Y.L. Han, X. Long and M.H. Wu, Enhancing upconversion luminescence of $\mathrm{NaYF}_{4}: \mathrm{Yb} / \mathrm{Er}$ nanocrystals by $\mathrm{Mo}^{3+}$ doping and their application in bioimaging, Dalton Trans. 43 (2014) 12037-12043. 


\section{Table Caption}

Table 1. Calculated values of temperature at different pump power densities corresponding to different $\mathrm{R}$ values of $\mathrm{La}_{2} \mathrm{O}_{3}: \mathrm{Er}^{3+} / \mathrm{Yb}^{3+}$ phosphors.

\section{Figure captions}

Figure 1. The X-ray diffraction patterns of $\mathrm{La}_{2} \mathrm{O}_{3}: \mathrm{xEr}^{3+}, \mathrm{yYb}^{3+}$ samples annealed at $800^{\circ} \mathrm{C}$ : (a) $\mathrm{x}=0.01 \mathrm{~mol}, \mathrm{y}=0.01 \mathrm{~mol}$; (b) $\mathrm{x}=0.01 \mathrm{~mol}, \mathrm{y}=0.03 \mathrm{~mol}$; (c) $\mathrm{x}=0.01 \mathrm{~mol}$, $\mathrm{y}=0.04 \mathrm{~mol} ;$ (d) $\mathrm{x}=0.01 \mathrm{~mol}, \mathrm{y}=0.02 \mathrm{~mol} ;(\mathrm{e}) \mathrm{x}=0.05 \mathrm{~mol}, \mathrm{y}=0.02 \mathrm{~mol}$. And reference date JCPDS 05-0602.

Figure 2. The FE-SEM images of $\mathrm{La}_{2} \mathrm{O}_{3}: \mathrm{Yb}^{3+}, \mathrm{Er}^{3+}$ nanocrystallines.

Figure 3. The UC luminescence spectra of $\mathrm{La}_{2} \mathrm{O}_{3}: \mathrm{xEr}^{3+}, \mathrm{yYb}^{3+}$ : (a) $\mathrm{y}=0.02 \mathrm{~mol} ; \mathrm{x}=$ 0.005, 0.01, 0.02, 0.03, 0.04, $0.05 \mathrm{~mol}$. and (b) $\mathrm{x}=0.01 \mathrm{~mol} ; \mathrm{y}=0.01,0.02,0.03,0.04$, 0.05 mol. Inset shows the variation of R/G (Red/Green) emission intensity ratio with the $\mathrm{Yb}^{3+}$ ions concentration.

Figure 4. The Pump power dependence of UC emission of $\mathrm{La}_{2} \mathrm{O}_{3}: 0.01 \mathrm{Er}^{3+}, 0.02$ $\mathrm{Yb}^{3+}$ nanocrystallines.

Figure 5. The energy level diagrams of $\mathrm{Yb}^{3+} / \mathrm{Er}^{3+}$ co-doped $\mathrm{La}_{2} \mathrm{O}_{3}$ under excitation of $980 \mathrm{~nm}$ and possible UC processes.

Figure 6. Temperature evolution of the $\mathrm{Er}^{3+} \mathrm{UC}$ emission spectra excited by $980 \mathrm{~nm}$ laser for the $\mathrm{La}_{2} \mathrm{O}_{3}$ : $0.01 \mathrm{Er}^{3+}, 0.02 \mathrm{Yb}^{3+}$ nanocrystalline from $313 \mathrm{~K}$ to $573 \mathrm{~K}$.

Figure 7. (a) The R $\left(\mathrm{I}_{530} / \mathrm{I}_{549}\right)$ of $\mathrm{Er}^{3+}$ green UC emissions for the ${ }^{2} \mathrm{H}_{11 / 2},{ }^{4} \mathrm{~S}_{3 / 2} \rightarrow{ }^{4} \mathrm{I}_{15 / 2}$ transitions relative to the temperature range of 313-573 K; (b) The monolog plot of 
the $\mathrm{R}$ versus $1 / \mathrm{T}$ for the $\mathrm{La}_{2} \mathrm{O}_{3}: 0.01 \mathrm{Er}^{3+}, 0.02 \mathrm{Yb}^{3+}$ phosphor.

Figure 8. The sensor sensitivity $\mathrm{S}=\mathrm{dR} / \mathrm{dT}$ as a function of the temperature for $\mathrm{La}_{2} \mathrm{O}_{3}$ : $0.01 \mathrm{Er}^{3+}, 0.02 \mathrm{Yb}^{3+} . \mathrm{S}_{2}$ represents the value of experiment sensitivity.

Figure 9. The UCL spectra of the green bands ${ }^{2} \mathrm{H}_{11 / 2}{ }^{4} \mathrm{~S}_{3 / 2} \rightarrow{ }^{4} \mathrm{I}_{15 / 2}$ of $\mathrm{Er}^{3+}$ with different pump power for $\mathrm{La}_{2} \mathrm{O}_{3}: 0.01 \mathrm{Er}^{3+}, 0.02 \mathrm{Yb}^{3+}$. Inset: $\mathrm{R}$ as a function of laser pump power.

Figure 10. Cell viability assessment with HeLa cells with different concentration of $\mathrm{La}_{2} \mathrm{O}_{3}$ nanocrystalline.

Figure 11. (a) bright-field image of HeLa cells; (b) confocal image of HeLa cells after incubation with $\mathrm{Er}^{3+} / \mathrm{Yb}^{3+} \mathrm{La}_{2} \mathrm{O}_{3}$, collected at green (520 nm-570 nm) channels; (c) the overlay of bright-field image and panels (b). 
Table 1.

\begin{tabular}{|c|c|c|}
\hline Power density $\left(\mathrm{W} / \mathrm{cm}^{2}\right)$ & $\mathrm{R}$ & Temperature (K) \\
\hline 7.08 & 0.278 & 299 \\
\hline 7.78 & 0.280 & 300 \\
\hline 9.91 & 0.297 & 305 \\
\hline 13.45 & 0.329 & 313 \\
\hline 16.28 & 0.355 & 319 \\
\hline 16.99 & 0.361 & 321 \\
\hline 17.69 & 0.366 & 322 \\
\hline 19.10 & 0.380 & 325 \\
\hline 19.82 & 0.389 & 327 \\
\hline 20.52 & 0.395 & 329 \\
\hline
\end{tabular}




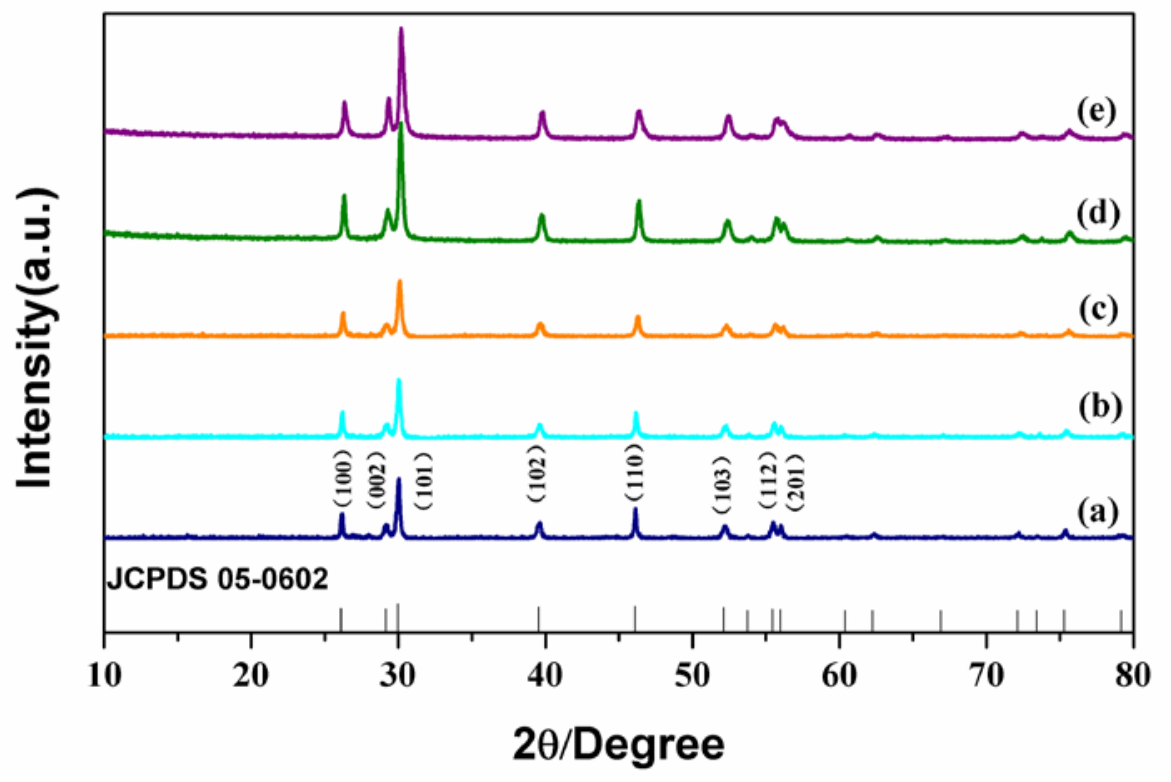

Figure 1. 


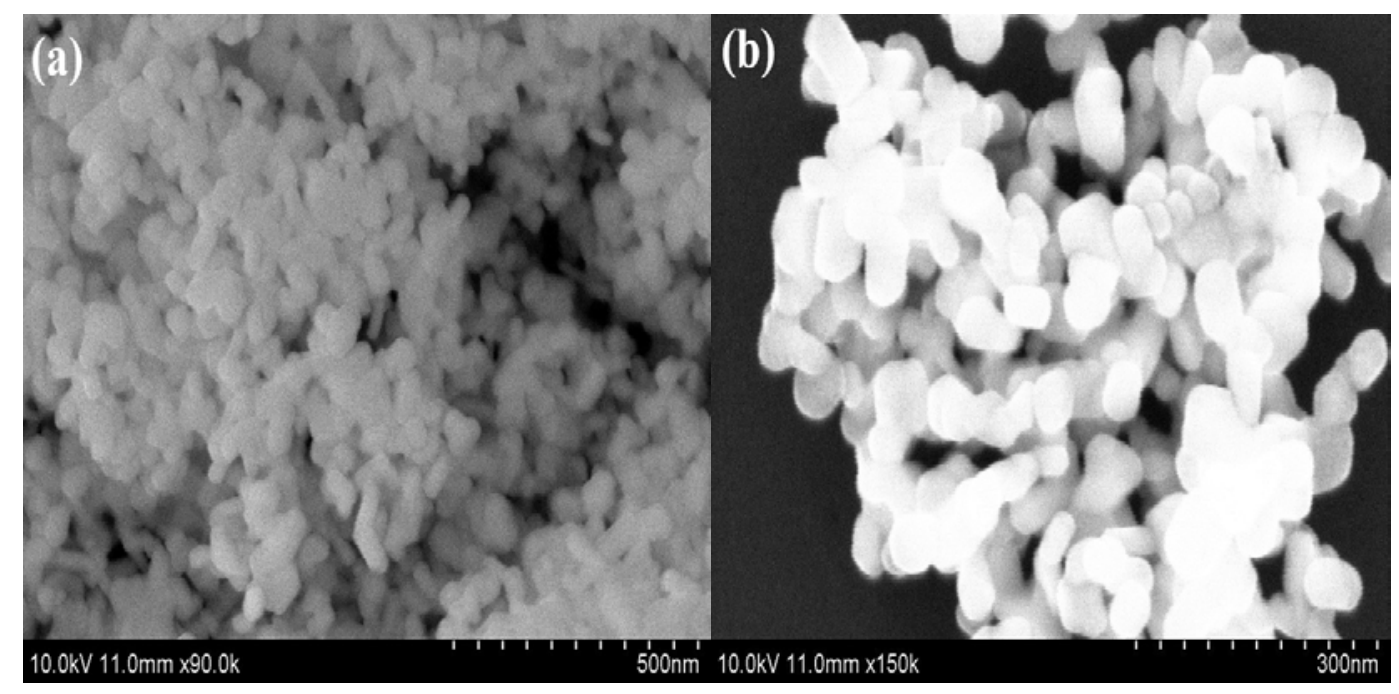

Figure 2. 


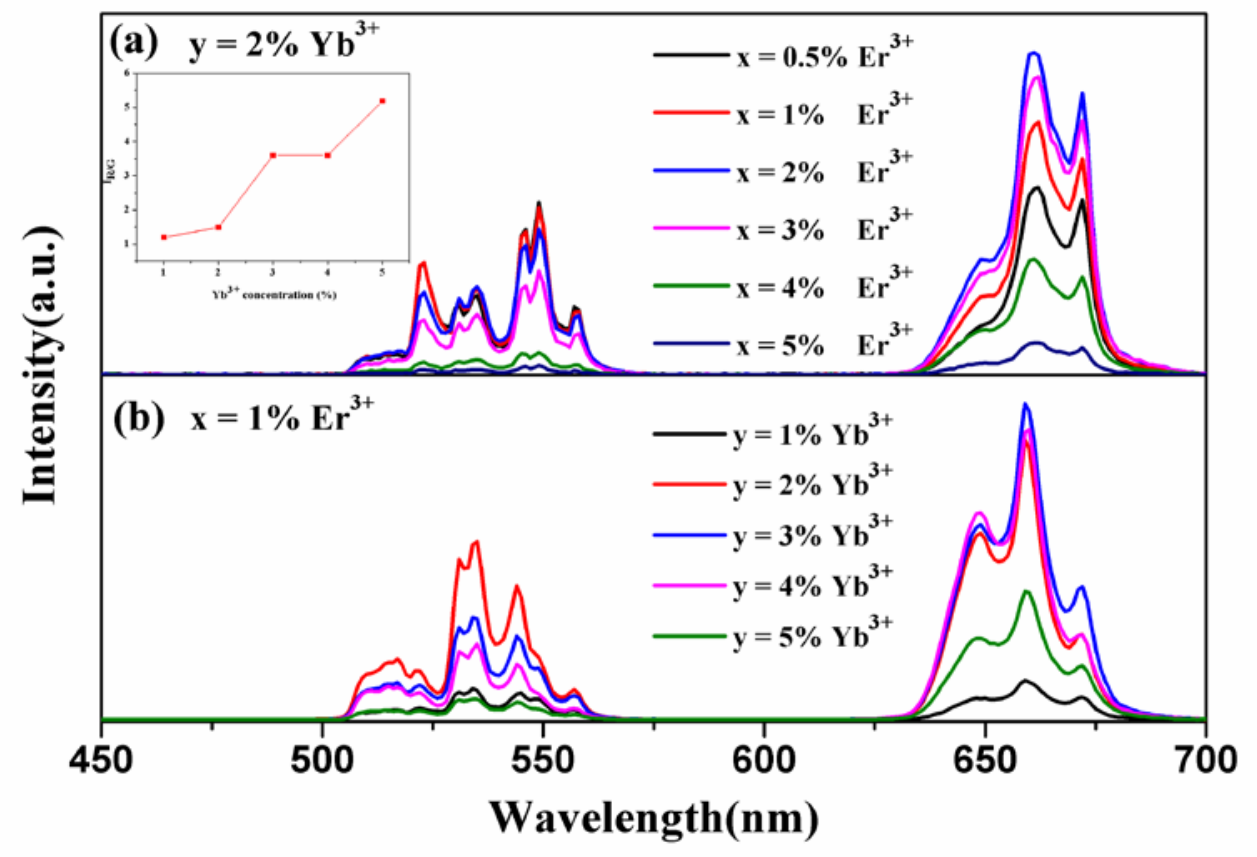

Figure 3. 


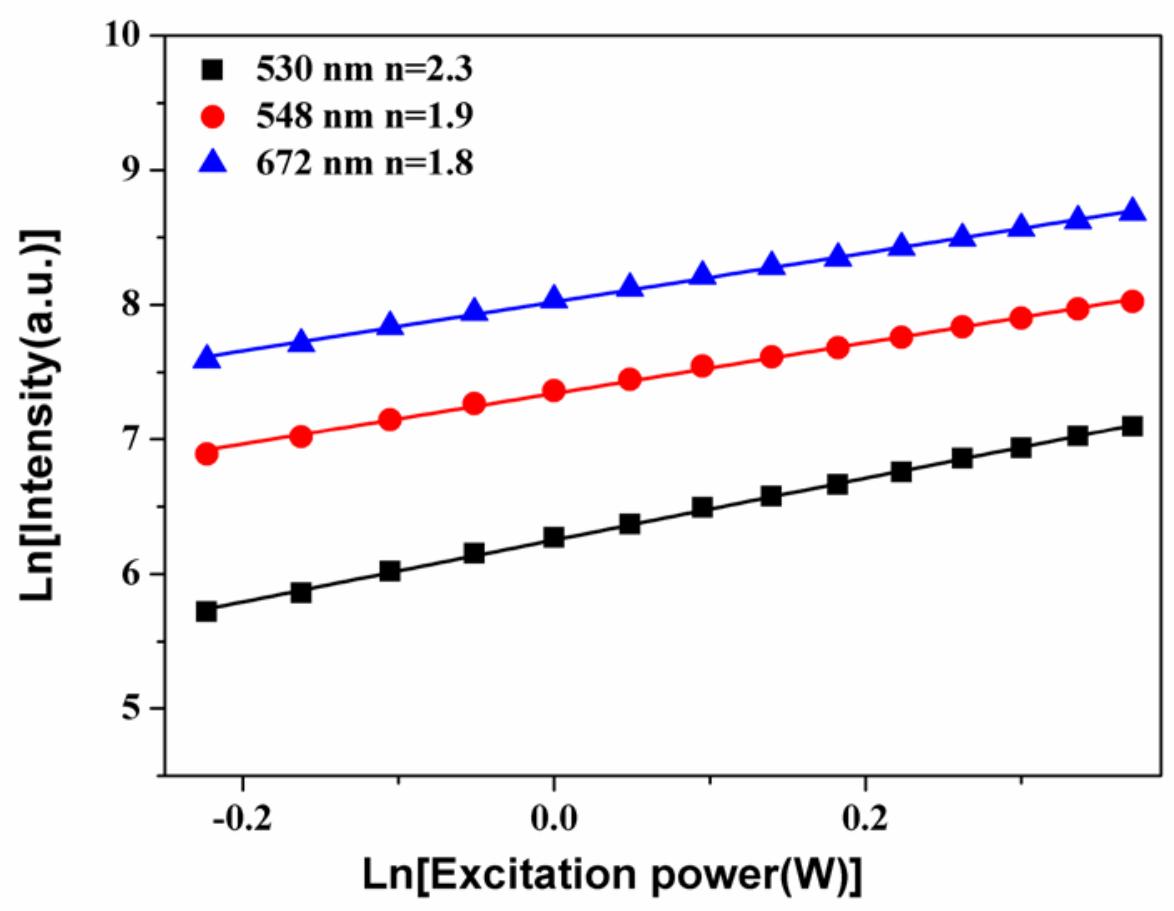

Figure 4. 


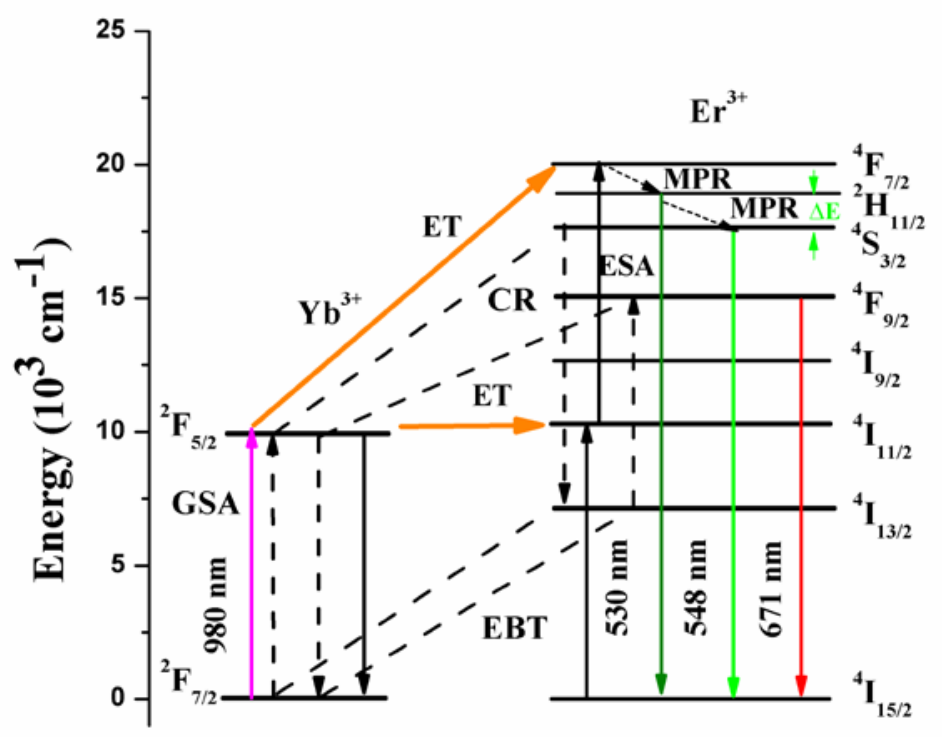

Figure 5. 


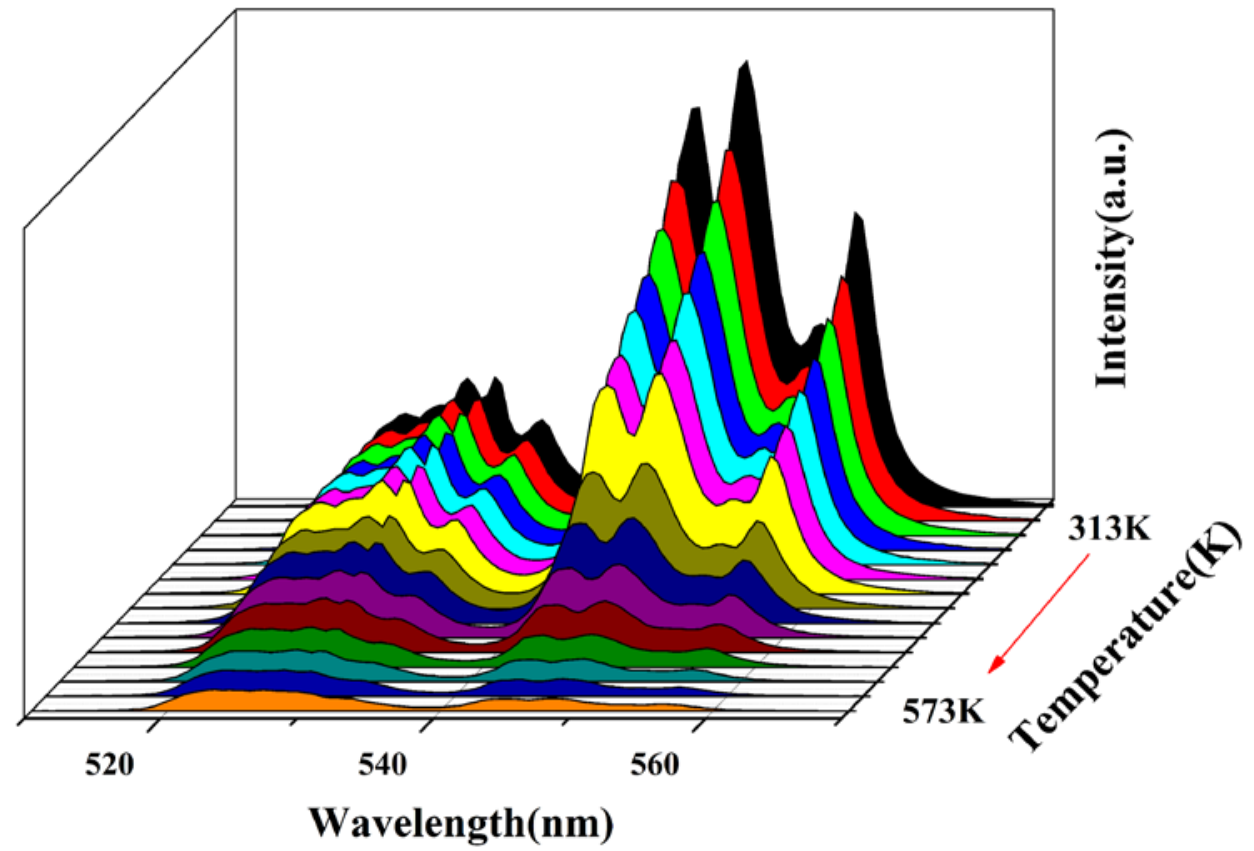

Figure 6. 

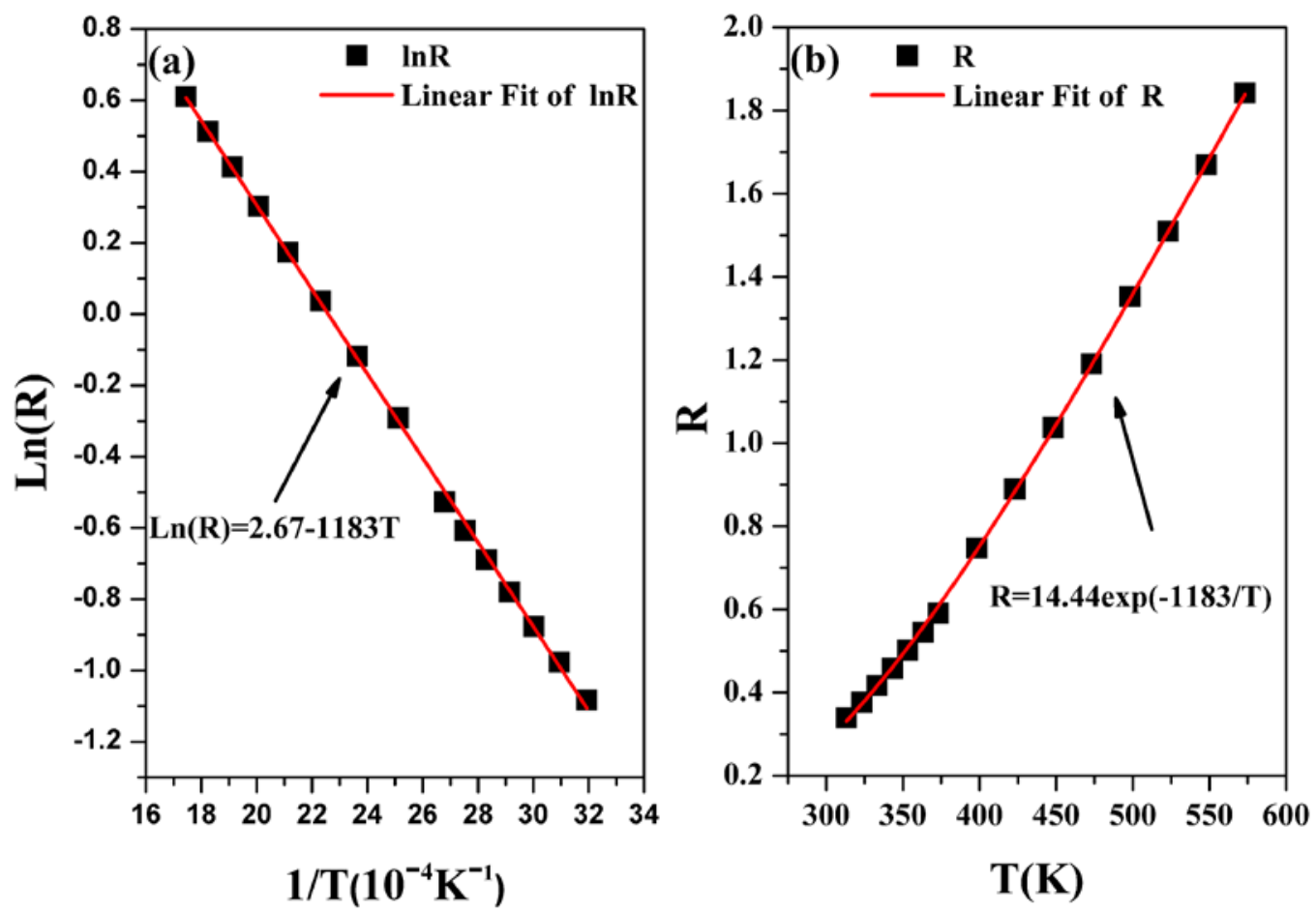

Figure 7. 


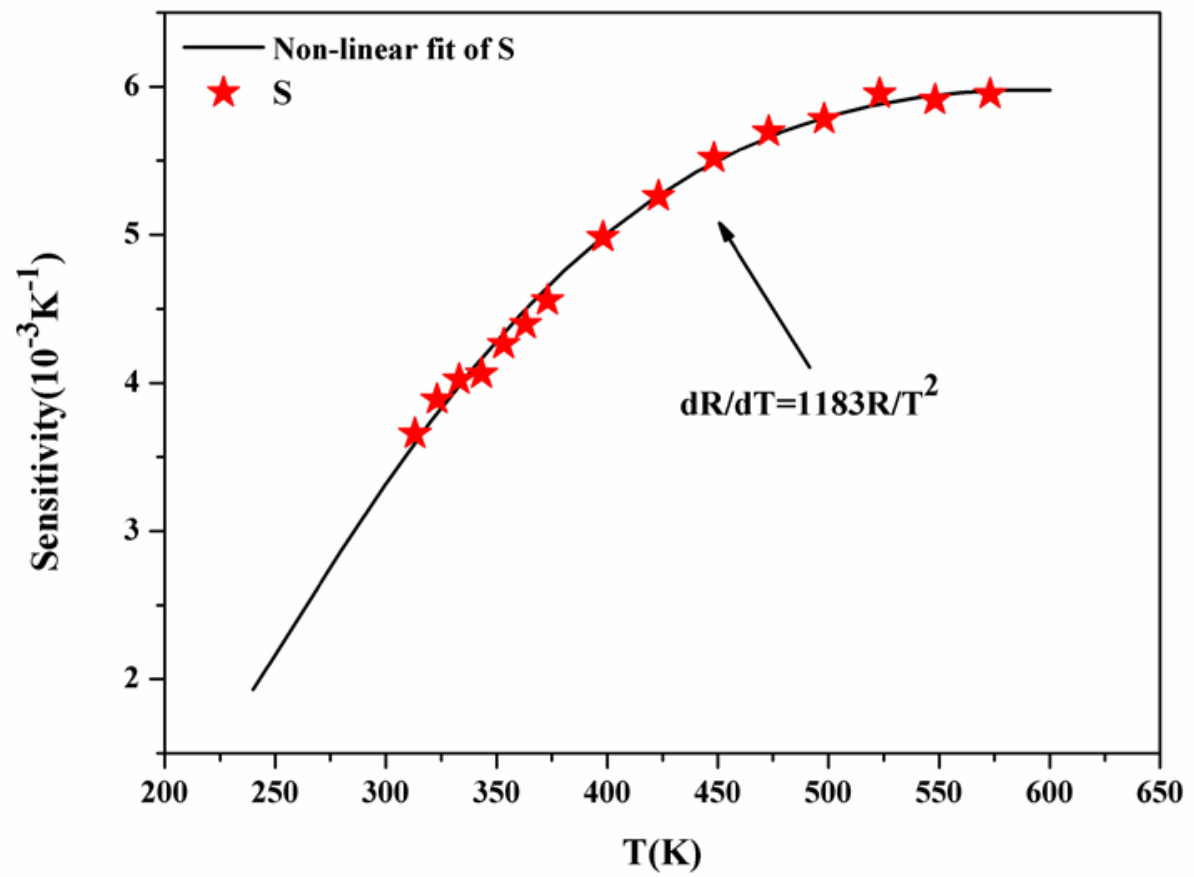

Figure 8. 


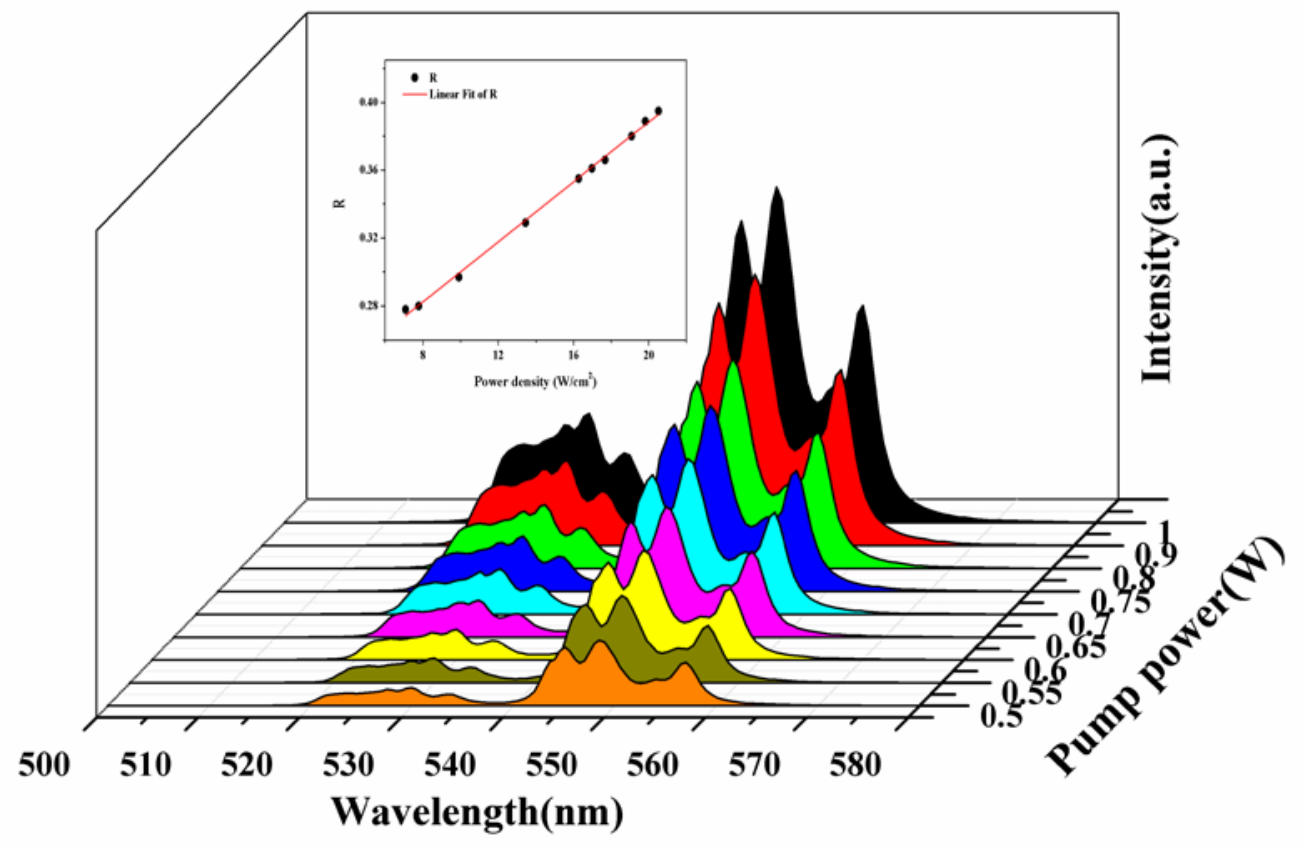

Figure 9. 


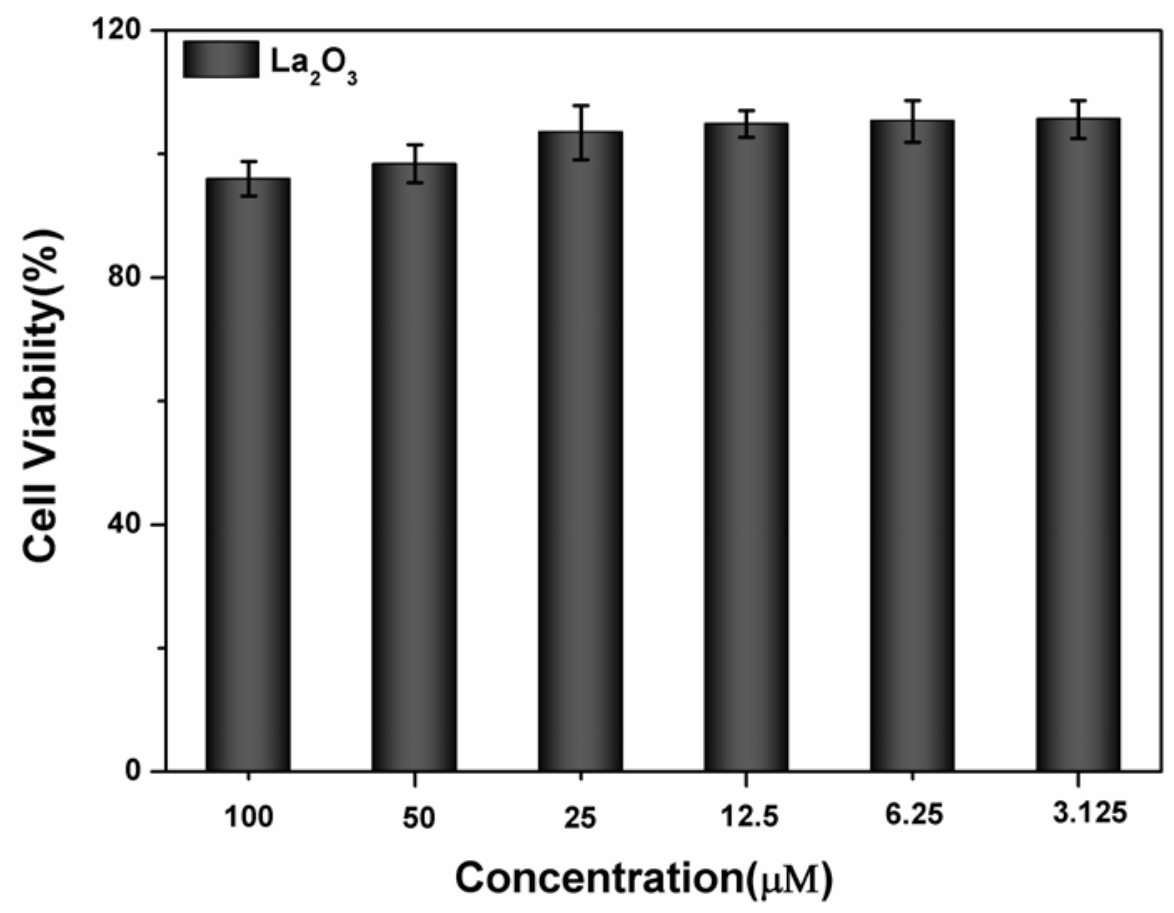

Figure 10. 


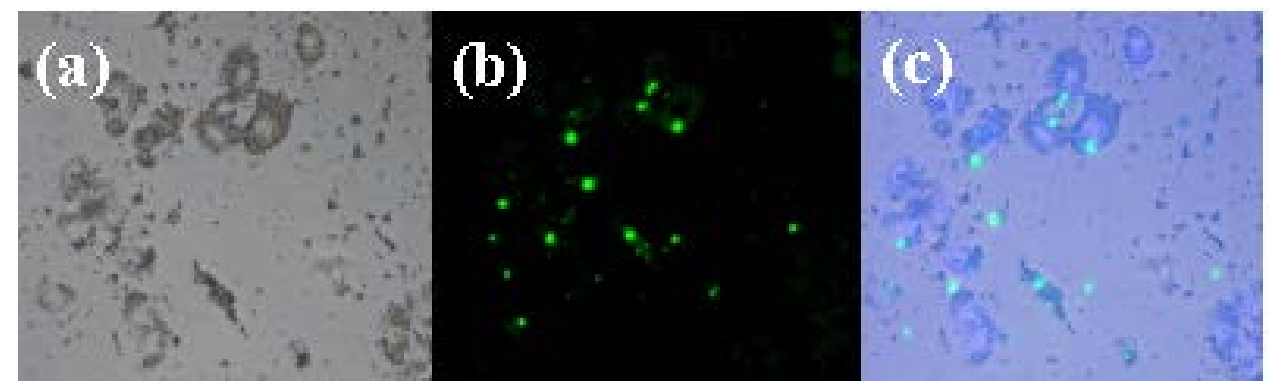

Figure 11 